SHRSP に扣けるエイコサペンタェン酸の長期投与の影響 一生存率，脂質代謝，脳血管和よび実験的 脳虚血に及ぼす影響の検討一

柏木 史彦片山泰朗目々澤肇赫彰郎

要旨：EPA（eicosapentaenoic acid）をSHRSP に長期経口投与を行ない，生存率，脂質代 謝，および脳血管に及ぼす影響について走查型電子顕微鏡を用いて中大脳動脈内腔につき検討 を行なった。ささらに実験的脳虚血モデルを作成し脳浮腫および脳代謝に及ぼす影響につき検討 した. 生存率は EPA 投与群にて高值を示し, 血清脂質の検討では HDL の高値を示した。病理 学的検討では EPA 投与群では SHRSP に加齢に伴い生じる血管内皮細胞の障害が軽度であっ た. 実験的脳虚血モデルでは, EPA 投与群で脳含水量は低值を示し脳代謝諸量では pyruvate の増加扣よび lactate/pyruvate 比の減少を認めた。 EPA の長期投与はSHRSP の死亡率を低 下させ, 脳虚血後に生じる脳浮腫および脳代謝障害を軽減させることが示唆された。

Key words : EPA, SHRSP, endothelium of MCA, experimental cerebral ischemia (脳卒中12 : 326-333, 1990)

\section{緒言}

脳卒中は, 我が国において近年その死亡率の第 1 位 の座を譲ったとはい光, 脳血栓症は依然高い発生率を 有し，その予防および治療法の確立は重要である。脳 血栓症はその多くが高血圧症, 高脂血症および糖尿病 等を基礎疾患として発生する動脈硬化症を基盤として 発症することが知られている11.

近年 Dyerberg らにより，魚を多量に摂取するグ リーンランドに住むエスキモーに脳血栓症を始めとす る血栓性疾患が少ないとする報告2)がなされて以来, 主に魚油中に多く含まれる多価不飽和脂肪酸である土 イコサペンタェン酸（eicosapentaenoic acid:EPA） の持つ抗血栓作用が注目されるよらになった。

一方, 高血圧を伴った脳卒中の発生モデルとして知 られている脳卒中易発症高血压自然発症ラット (Stroke-prone spontaneously hypertensive rat: SHRSP)は, 加龄に伴い著しい高血圧を生じ, 高率に 脳卒中を発生し死亡すること ${ }^{3)}$ ，拉よび実験的な虚血 侵襲により高度の脳浮腫および脳循環代謝障害を来た すことが報告されている4)5)。これらの観点より今回著

日本医科大学第二内科
者らは, SHRSP に EPA ethylester (EPA-E) を長期 にわたり経口投与し生存率を観察するとともに, 血中 脂質および脂肪酸組成に及ぼす影響について検討を行 なった。 また, 長期の EPA 投与が脳血管に及ぼす影響 についても電子顕微鏡を用いて病理学的検討を行なっ た。ささらに, EPA 投与後実験的脳虚血を作成し, 虚血 によって生じる脳浮腫および脳代謝障害に対する EPAの長期前投与の影響を検討した。

\section{対象および方法}

\section{1. 対象および薬物投与方法}

実験には, 8 週齢の体重 $140 \mathrm{~g}$ 前後の雄の SHRSP, 80匹を使用した。これらのラットをあらかじめオリェ ンタル酵母社製 MF 粉末飼料にて 7 週間予備飼育し た後無作為に40匹ずつ 2 群に分け, 1 群には MF 飼料 に EPA ethylester (EPA-E) $100 \mathrm{mg} / \mathrm{kg} /$ day を混じて 与え, 他の 1 群には MF 飼料のみを与えこれを対照群 とした. EPA-Eを混じた飼料は脂質の過酸化を防ぐた め投与前まで泠所（ $5{ }^{\circ} \mathrm{C}$ 以下）にて保管した。

\section{2. 生存率の検討}

EPA-E 投与開始より 25 週間, 約 $5 \sim 6$ 週間ごとに体 重および血圧を測定しさらに生存率を調べた。血圧の 測定は tail cuff 法（夏目製作所製）による非観血的方 
法により測定した.

\section{3. 血中脂質および脂肪酸組成の検討}

EPA-E 投与開始 25 週後に，1.5\%フローセンを含有 する酸素吸入下に腹部大動脈にカテーテルを扥入し採 血を行い, 採取後直ちに血清を分離し速やかに凍結し 脂質および全脂質構成脂肪酸分画の測定試料とした。 血清脂質は total cholesterol（T-ch）を酵素法にて， triglyceride (TRG) は GPODAOS 法にて, LDL は等 電点分画法にて，さらに HDL は heparin $\mathrm{Ca}-\mathrm{Ni}$ 沈殿 法にて各々検討を行なった。 また，脂肪酸組成の分析 は gaschromatography 法にて行なった。

\section{4. 病理学的検討}

病理学的検討は EPA-E 投与開始25週後に, EPA-E 投与群および対照群それぞれ 5 匹ずつを使用して行 なったＥEA-E投与群および対照群それぞれを $1.5 \%$ フローセンを含有する酸素吸入下に腹部大動脈にカ テーテルを插入し，グルタールアルデヒドおよび $2 \%$ パラホルムアルデヒドを燐酸緩衝液にて調整した固定 液（pH 7.4，浸透生500mOsm）にて, $200 \mathrm{cmH}_{2} \mathrm{O}$ の 圧にて15分間灌流固定を行なった。 その後脳を採取し, microtomeにより中大脳動脈の斜断面を得, 走査電子 顕徽鏡標本とした。観察は日立 S-405型走査電子顕微 鏡（倍率2,000倍, 観察電圧 $25 \mathrm{kv}$ )を用いて, 中大脳動 脈内腔を観察した。

\section{5. 実験的脳虚血モデルの作成}

$\mathrm{EPA}-\mathrm{E}$ 投与開始25週後に, EPA-E 投与群および対 照群それぞれ 6 匹ずつを使用し，実験的脳虚血モデル を作成した. $1.5 \%$ フローセンを含有する酸素吸入下に 頝部を正中切開後両側総頝動脈を露出し二重結禁 （BLCL）を行なうことにより脳虚血を作成した，虚血 作成後は自然呼吸とし, BLCL 3 時間後に頭部にマイ クロウェーブを照射 (東芝製, 出力 $5 \mathrm{kw}$ ，照射時間 1.5 秒）後, 脳を摘出し, 前頭部にて脳含水量を頭頂部に て脳代謝諸量を測定した。脳含水量は真空凍結乾燥機 （大亜真空技研製）を用いた凍結乾燥法にて測定した。 脳代謝諸量の検討はATP, lactateおよび pyruvate を測定して行なった。ATPの測定はluciferinluciferaseを用いた bioluminescence 法にて, lactate および pyruvateはLDHを用いた ultra-violet 法に て行なった。

\section{結＼cjkstart果}

1. 体重および血圧の変化

Table 1 に示す様に, 体重の変化は, EPA-E 投与群
Table 1 Physiological parameters in SHRSP after EPA administration

Each value represents mean \pm S.D.

Number in parenthesis is number of animals

\begin{tabular}{|c|c|c|c|c|}
\hline \multirow{2}{*}{$\begin{array}{c}\text { Age } \\
\text { (week) }\end{array}$} & \multicolumn{2}{|c|}{ Body Weight (gr) } & \multicolumn{2}{|c|}{ Blood Pressure $(\mathrm{mmHg})$} \\
\hline & Treated & Untreated & Treated & Untreated \\
\hline 8 & $224.4 \pm 14.0(40)$ & $223.9 \pm 6.0(40)$ & $231.0 \pm 24.9(40)$ & $231.4 \pm 9.6(40)$ \\
\hline 18 & $288.3 \pm 11.5(40)$ & $282.2 \pm 16.4(40)$ & $262.3 \pm 14.1(40)$ & $246.9 \pm 17.2(40)$ \\
\hline 23 & $297.2 \pm 12.0(40)$ & $294.4 \pm 14.2(38)$ & $248.3 \pm 19.8(40)$ & $252.9 \pm 10.5(38)$ \\
\hline 33 & $326.1 \pm 10.2$ & $313.1 \pm 21.7(27)$ & $258.4 \pm 17.2$ & $271.0 \pm 15.9(27)$ \\
\hline
\end{tabular}

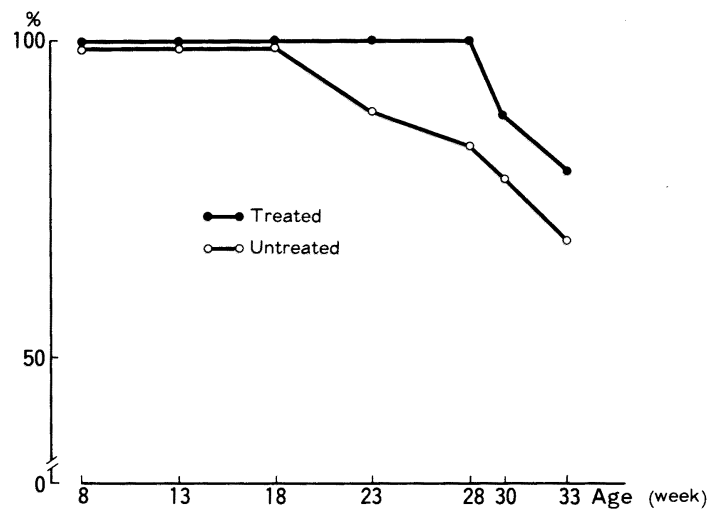

Fig. 1 Effect of administration of EPA on survival ratio. Note that the EPA treated group has a higher survival rate.

と対照群との間に有意な差異は認められなかった。一 方，血圧においては33週では EPA-E投与群では対照 群に比べて有意差は認めないが低值を示す傾向があっ た。

\section{2. 生存率の検討}

EPA-E 投与開始10週後18週齢では両群とも $100 \%$ の 生存率であり EPA-E 投与群と対照群との間に生存率 に差異はなかった。投与開始15週後（23週齢）では EPA-E 投与群は $100 \%$ 生存率を示したのに対して対 照群は $94 \%$ の生存率であり, EPA-E 投与群はその後も 20週後 (28週齢) まで100\%の生存率であったのに対し て，対照群は漸次減少を示した。 25週後（33週歯）で は EPA-E投与群では $80 \%$ であり，対照群は $68 \%$ と低 値であった（Fig. 1).

\section{3. 血清脂質の検討}

血清脂質の検討では, Table 2 に示すごとく T-ch, TRG およびLDL の值には EPA-E 投与群と対照群と の間に有意な差異を認めなかった。 HDLの值は 
EPA-E 投与群では50.30 $\pm 8.84 \mathrm{mg} / \mathrm{d} l$ (mean士S.D.), 対照群では $38.3 \pm 6.59 \mathrm{mg} / \mathrm{d} l$ であり $\mathrm{EPA}-\mathrm{E}$ 投与群に て有意に高值を示した $(\mathrm{p}<0.05)$ 。また， atherogenic index は EPA-E 投与群で $0.23 \pm 0.10$, 対照群で $0.40 \pm$ 0.11 でり EPA-E投与群にて有意に低值を示した $(\mathrm{p}<0.05)$.

Table 2 Effect of administration of EPA on plasma lipid levels

Values indicate mean \pm S.D. Abbreviation: $\mathrm{T} \cdot \mathrm{ch}=$ Total cholesterol, $\mathrm{TRG}=$ Triglyceride, A.I. $=$ Ather ogenic index ( $\mathrm{T}$-ch-HDL/HDL)

The concentration of T-ch, TRG and HDL are indicated as $\mathrm{mg} / \mathrm{d} l$.

Statistical differences between the treated and the untreated group : $\mathrm{p}<0.05$, N.S. $=$ No Significance. $\mathrm{n}=$ number of animals

\begin{tabular}{|c|c|c|c|c|c|c|}
\hline & $n$ & T-cho & TRG & LDL & HDL & A.I. \\
\hline \multirow[t]{2}{*}{$\begin{array}{l}\text { Treated } \\
\text { Group }\end{array}$} & 8 & $61.0 \pm 8.23$ & $50.0 \pm 3.427$ & $134.3 \pm 25.597$ & $50.3 \pm 8.84$ & $0.23 \pm 0.10$ \\
\hline & & N.S & N.S & N.S & $P$ & $\mathrm{P}$ \\
\hline $\begin{array}{l}\text { Untreated } \\
\text { Group }\end{array}$ & 8 & $53.2 \pm 5.84$ & $47.8 \pm 12.5$ & $117.2 \pm 36.40$ & $38.3 \pm 6.59$ & $0.40 \pm 0.11$ \\
\hline
\end{tabular}
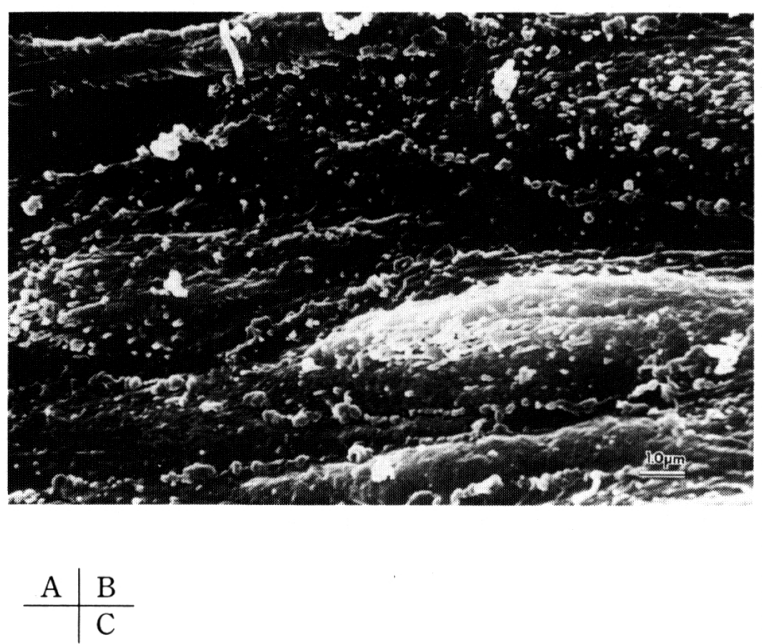

Fig. 2 Scanning electron micrographs of MCA luminal surfaces of SHRSP in control group. A : A large number of microvilli and marked protrusion in the center of endothelial cells could be seen. B: Desquamation of the endothelial membrane was observed. C: Red blood cells trapped by fibrin nets could be seen.

\section{4. 血浆脂肪酸分画の検討}

血浆脂肪酸分画では C20 : 5 (eicosapentaenoic acid:

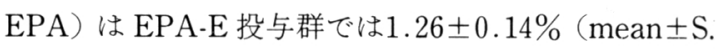
D.)であり, 対照群では $0.94 \pm 0.16 \%$ EPA-E 投与群 にて有意に高值を示した $(\mathrm{p}<0.02)$. C20:4（arachidonic acid : A.A) 特よび C22:6 (docosahexaenoic acid：DHA）ではEPA-E 投与群と対照群との間に有 意な差異はなかった。㐬な，EPA/A.A 比は EPA-E 投 与群では5.04 0 0.66, 対照群では $3.37 \pm 0.50$ と EPA-E 投与群にて有意に高值を示した $(\mathrm{p}<0.01$, Table 3$)$.

\section{5. 病理学的検討}

中大脳動脈内腔の走査型電子顕微鏡による観察で は, 対照群に招いては内皮細胞表面に多数の microvilli の増生が認められた。 また, 血管内皮細胞に扣いて中 央部に膨隆をさたすもの (Fig. 2A) や表層の剝離をき たすもの (Fig. 2B) が認められた. その他一部では赤 血球が fibrinに捕捉されている所見も認められた (Fig. 2C). EPA 投与群では microvilli の増生は認め られるものの, 対照群で認められた内皮細胞の膨隆や 剥離の所見はみられなかった (Fig. 3).

6. 実験的脳虚血モデルにおける検討

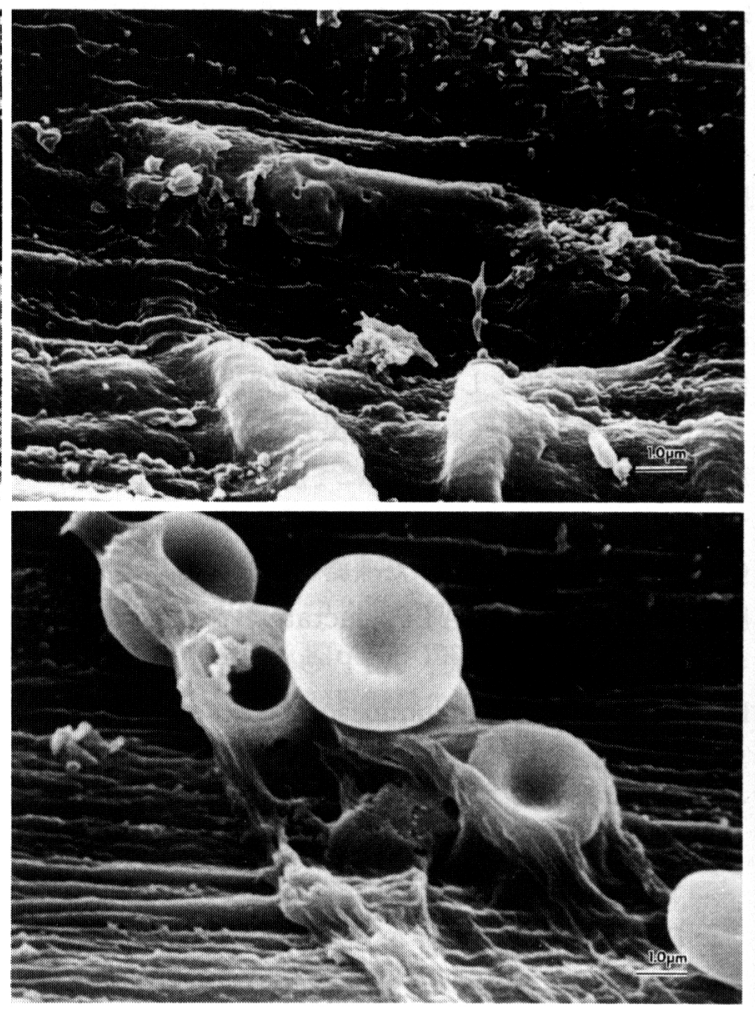


Table 3 Effect of administration of EPA on plasma fatty acid composition in SHRSP

Values indicate mean \pm S.D. Abbreviation : EPA = Eicosa pentaenoic acid, A.A. $=$ Arachidonic acid, DHA = Docosahexaenoic acid

Fatty acid composition and EPA/A.A. ratio were indicated as percent.

Statistical differences between the treated and the untreated group : ${ }^{*} \mathrm{p}<0.02,{ }^{* *}$ $\mathrm{p}<0.01$, N.S. $=$ No Significance

\begin{tabular}{|c|c|c|c|c|c|}
\hline & $\mathrm{n}$ & $\operatorname{EPA}\left(\mathrm{C}_{20: 5}\right)$ & A.A. $\left(\mathrm{C}_{20 ; 4}\right)$ & $\mathrm{DHA}\left(\mathrm{C}_{22 ; 6}\right)$ & EPA/A.A. \\
\hline \multirow[t]{2}{*}{ Treated Group } & 8 & $1.26 \pm 0.14$ & $25.24 \pm 0.93$ & $5.64 \pm 0.37$ & $5.04 \pm 0.66$ \\
\hline & & $\mathrm{P}$ & & & $P$ \\
\hline Untreated Group & 8 & $0.94 \pm 0.16$ & $24.48 \pm 1.47$ & $5.26 \pm 0.29$ & $3.37 \pm 0.50$ \\
\hline
\end{tabular}

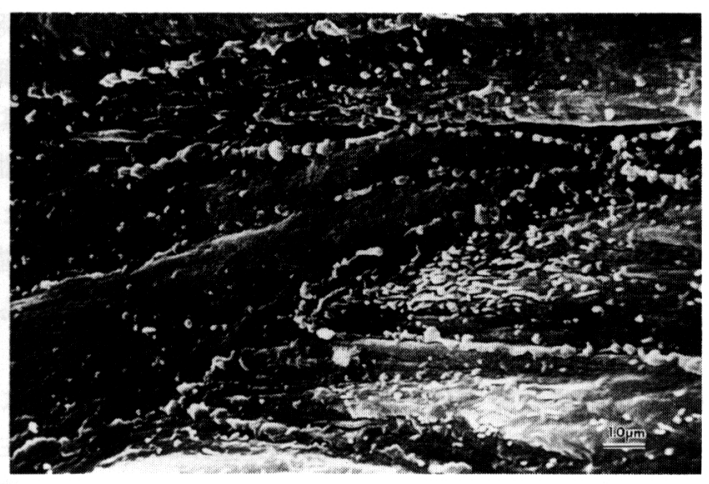

Fig. 3 Scanning electron micrographs of MCA luminal surfaces in EPA administrated group. Note that protrusion and desquamation of the endothelial surfaces were not observable.

Table 4 Effect of EPA on brain metabolites $3 \mathrm{hr}$ of ischemia induced by BLCL

Values indicated mean \pm S.D.

Statistical differences between the treated and the untreated group : $\mathrm{p}<0.05$, N.S. $=$ No Significance The concentration of ATP, lactate and pyruvate was indicated as nmols/mg brain.

\begin{tabular}{lccccc}
\hline & $n$ & ATP & Lactate & Pyruvate & L/P \\
\hline Treated Group & 12 & $0.32 \pm 0.22$ & $17.2 \pm 11.4$ & $0.24 \pm 0.05$ & $99.8 \pm 46.4$ \\
& & \multicolumn{2}{c}{ N.S. } & N.S. & P \\
Untreated Group & 12 & $0.31 \pm 0.26$ & $16.5 \pm 13.5$ & $0.17 \pm 0.09$ & $167.3 \pm 63.0$ \\
\hline
\end{tabular}

両側総頝動脈結禁 3 時間後の脳含水量の検討では, 脳含水量は EPA-E 投与群で78.53土0.79\% (mean士 S.D.) であり対照群の79.30土0.65\%に比べ EPA-E 投 与群で有意に低值を示した $(\mathrm{p}<0.01$, Fig. 4). 脳代謝

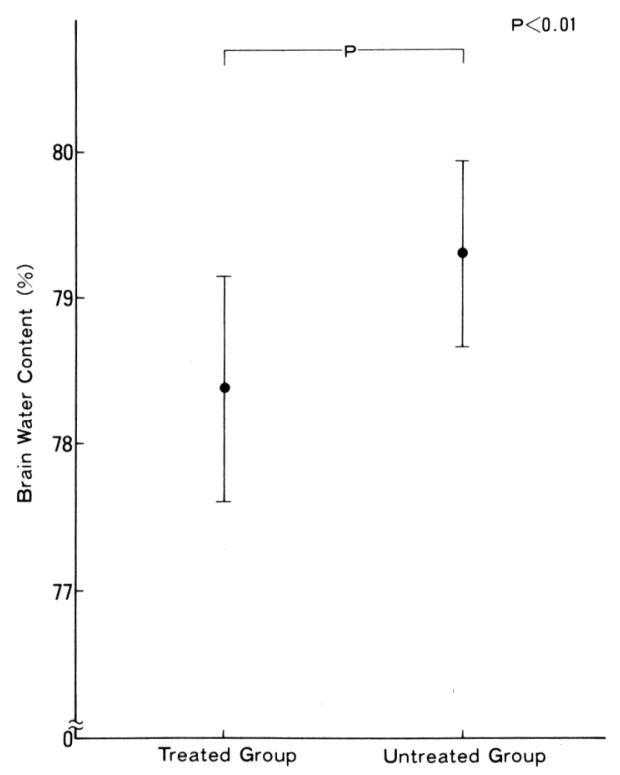

Fig. 4 Effect of EPA on brain water content $3 \mathrm{hr}$ after BLCL. The brain water content in the EPA administrated group was lower than that of control group. The circle and the bar indicated mean \pm S.D..

諸量の検討では, Table 4 に示すごとく ATPは EPA-E 投与群にて0.32 $00.22 \mathrm{nmols} / \mathrm{mg}$ brain, 対照 群では0.31土0.26nmols/mg brainであり, 両群間に 有意な差異を示さなかった. Lactate は, EPA-E 投与 群で17.2土11.4nmols/mg brain, 対照群では16.5土 $13.5 \mathrm{nmols} / \mathrm{mg}$ brain であり両群間に有意な差異はな かった.一方, pyruvate は EPA-E 投与群にて0.24士 $0.05 \mathrm{nmols} / \mathrm{mg}$ brain, 対照群では0.17士0.09nmols/ $\mathrm{mg}$ brainと EPA-E投与群にて有意に高值を示し 
( $\mathrm{p}<0.05)$, lactate/pyruvate 比は EPA-E 投与群では $99.8 \pm 46.4$, 対照群では167.3土63.0であり EPA-E 投 与群において有意に低值を示した $(\mathrm{p}<0.05)$.

\section{考案}

Dyerberg らの報告 ${ }^{2}$ 以後 EPA の持つ抗血栓作用が 注目され，その作用機序についてこれまで多くの研究 がなされている. EPA の抗血栓作用は, 血清脂質の改 善 ${ }^{677}$, 血小板凝集の抑制 ${ }^{688}$, 赤血球変形能の六進 ${ }^{6)}$, 血 液粘度の低下 ${ }^{9)}$, 血管壁での $\mathrm{PGI}_{2}$ や $\mathrm{PGI}_{3}$ 産生の増 加 $^{10)}, \mathrm{TXA}_{2}$ の減少と $\mathrm{TXA}_{3}$ の産生 ${ }^{1112)}$, 血圧の低下作 用13114)などさまざまな機序を介して発現すると考光ら れているがその詳細は未だ明らかではない。

一方, SHRSP は加齢に伴い著しい高血圧を来たし， 高率に脳卒中を発症することから脳卒中の良い動物も デルとして使用されており ${ }^{3)}$, 脳卒中発現前に $\mathrm{TXA}_{2}$ と $\mathrm{PGI}_{2}$ のバランスが崩壊し脳卒中発現に至ることも 知られている15).

今回, 抗血栓作用を始めとした様々な生物学的活性 を持つEPA を長期にわたり SHRSP に経口投与し, EPA の脳卒中発症に対する予防効果招よび実験的脳 虚血による虚血障害程度に及ぼす影響について検討を 行なった.EPA-E 投与後の体重および血圧の変化をみ てみると, Table 1 に示す様に体重は EPA-E 投与群 と対照群との間に有意な差異はなく EPA 投与による 消化吸収障害などの影響はないものと考光られた。一 方, 血圧の推移をみてみると, EPA-E 投与群では26週 以後では有意ではないが対照群に比べ低值をとる傾向 を示した. EPA の投与が血圧を低下させるとの報告は これまで少なからずみられる13141).

生存率の検討では, 23週龄以後においては EPA-E 投与群は対照群に比べ高い生存率を示した. SHRSP は，その経過において高率に脳卒中を発症するが3), $\mathrm{EPA}$ の投与は脳卒中発症を抑制する可能性が示唆さ れた。

EPA の脂質代謝に及ぼす影響に関しては, 田村ら ${ }^{16)}$ は，高脂血症の患者に EPA を投与したところ，T-ch およびTRGは有意に低下したが HDLには変化がな かったとしている. Lossonczy ${ }^{17)}$ は健常者にサバを摂 取させることにより血中の LDL の低下と共に HDL の上昇を認めたと報告している，今回の実験では, T-ch，TRG 拈よびLDLに打いてはEPA-E 投与群と 対照群との間には有意な差異は認められなかったが, HDL は EPA-E 投与群にて高値を示し，EPA 投与は
脂質代謝に影響を及ぼしていることが示唆された。 $\mathrm{EPA}-\mathrm{E}$ の投与量はヒトでは $60 \mathrm{mg} / \mathrm{kg}$ の投与にて有意 に血小板凝集能が低下しだ) とされ，ラットでは240

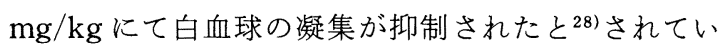
ることより，今回の実験では投与量を $100 \mathrm{mg} / \mathrm{kg}$ とし たが, 今回の結果と Lossonczy らの報告との相違は, $\mathrm{EPA}$ の投与量の差 ${ }^{18)}$ や動物の種差 ${ }^{19)}$ などによるとも 考えられる。

EPA-E 投与による血中脂肪酸組成への影響の検討 では, EPA-E投与群では EPA は対照群に比べ有意に 上昇したが，A.A 拉よび DHA は変化を示さなかっ た. EPA A A.A と同様 cyclooxygenase の基質とな り，血小板と血管組織でそれぞれ $\mathrm{TXA}_{3}$ および $\mathrm{PGI}_{3}$ に代謝される。 $\mathrm{TXA}_{3}$ は $\mathrm{TXA}_{2}$ のような強い血小板凝 集作用を示さないのに対し, $\mathrm{PGI}_{3}$ は $\mathrm{PGI}_{2}$ と同様な強 力な血小板凝集抑制作用を示す1112). しかし, EPAは cyclooxygenase の基質としては不十分で，その代謝 産物である $\mathrm{PGI}_{3}$ や $\mathrm{TXA}_{3}$ の産生量は非常に少ないと されている。むしろ EPA は血小板に打いて A.A 代謝 を cyclooxygenase レベルで拮抗的に㗢き ${ }^{12)}, \mathrm{TXA}_{2}$ の産生を減少させていると考えられている。また， EPA 摂取により EPA/A.A 比を上昇させることによ り, 血小板の A.A 含量が低下し $\mathrm{TXA}_{2}$ の産生低下も生 ずると考えられ，このような機序を介して EPAが抗 血栓作用を発現するものと考えられる。しかし EPA の血小板凝集抑制作用はヒトでは明らかにされている もののラットでの報告は少ない20). Morita ら ${ }^{21)} の ラ ッ$ トでは脂肪酸の desaturase 活性が高いために EPA を投与してもリノール酸より A.A への多量の供給が おこり, EPA/A.A 比が上昇せず血小板凝集抑制作用 が起こり難い, とする報告もある。 SEM による中大脳 動脈内腔の観察において, EPA-E 投与群および対照群 の両群において血管内皮細胞に microvilli の増生が認 められた. Microvilli は脳の虚血状態に打いて増殖性 に発生し, 細胞表面積を増大させることにより酸素な ど脳代謝に必要な物質の吸収を増大させるとされてい る. Microvilli の増生 ${ }^{22)}$ は EPA-E 投与群および対照群 の間には差異が認められなかったが，血管内皮細胞の 退行的障害状態と考えられる内皮細胞の膨隆 ${ }^{23}$ は EPA 投与群では観察されなかった。 李た，血球成分や fibrin の付着も対照群にのみ認められた。 上記のごと く EPA 投与ラットでは血管内皮細胞の障害は軽減さ れた。このような $\mathrm{EPA}$ 投与による内皮細胞障害の軽 減怙よび血球成分や fibrin の付着の抑制が SHRSP の 
脳血栓症の発現を減少させて生存率の改善をもたらし たのかも知れない。をた，これらの血管内腔の病理学 的変化の改善は $\mathrm{EPA}$ 投与による血圧下降作用や脂質 代謝への作用が関連していることも考慮される。

一方，実験的脳虚血モデルに対する EPAの効果に 関して, Black ら ${ }^{26)}$ は砂ネズミに魚油を投与後一過性 脳虚血を作成し，魚油投与群に打いて血流再開後の脳 血流の改善および脳浮腫の軽減を認めたとしている。 今回, 我々の実験でも虚血後の脳含水量は EPA-E 投 与群において対照群に比べて有意に低值を示し,さらら に脳代謝においては pyruvate の増加および, lactate/ pyruvate 比の減少を認めた. これらの機序として前述 したごとく,EPA の投与により SHRSP の加齢ととも に生じる血管の病理学的変化, 特に内皮細胞障害が軽 減されたこと, 次いで加齢とともに進展する脳血流の 減少 ${ }^{25)}$ が EPA の投与により抑制されたことが考えら れる.さらにEPA は cyclooxygenase の基質としては 不適だが lipoxygenaseの基質となり，A.A 由来の lipoxygenase 産物とは生物学的活性の異なる種々の lipoxygenase 代謝産物が作られることが関与してい ると考觉られる ${ }^{26)}$. 南澤ら ${ }^{27)}$ はSHRを用いた脳虚血 に扣いて脳浮腫の発現にA.A由来の leukotriene （LT）の増加が重要であることを報告しているが, $\mathrm{EPA}$ 由来の $\mathrm{LTB}_{5}$ は白血球の凝集, 遊走および走化, lysosome 酵素の放出能拉よび bradykinin による血 管透過性亢進の増強能を有してはいるものの, その活 性は $\mathrm{LTB}_{4}$ と比較してはるかに弱いとされてい る ${ }^{28) 29)}$ 。をた, $\mathrm{LTA}_{5}$ は LT 水解酵素を抑制して $\mathrm{LTB}_{4}$ の産生を阻害することも明らかとなっている30).

\section{結 語}

SHRSP にEPA-E を長期にわたり経口投与しそその 生存率および血清脂質に及ぼす効果について検討し, また脳血管に及ぼす影響につき電子顕微鏡を用いて病 理学的検討を行なった。さらに実験的脳虚血モデルを 作成し, EPA の投与が虚血後の脳浮腫および脳代謝障 害に及ぼす影響につき検討を行なった。

1）生存率は，28週齢以後に损いて EPA-E 投与群が 対照群に比べ高値を示した。

2）血清脂質の検討では，T-ch 括よびTRGは $\mathrm{EPA}-\mathrm{E}$ 投与群と対照群との間に有意な差異はなかっ たが, HDL は EPA-E 投与群にて有意に高値を示し, athelogenic index の高値も示した。

3） SEM による検討では, EPA-E 投与群にて中大脳
動脈内腔の血管内皮細胞の障害が軽度であった。

4) 実験的脳虚血モデルの検討では, EPA-E 投与群 において対照群に比べ脳浮腫発生は軽度であり, 脳 ATP扣よびlactate は変化を示さなかったが, pyruvate の変化を認めた.

以上の結果より, EPA の長期投与は SHRSP の生存 率を改善し, 脳虚血後に生じる脳浮腫および脳代謝障 害を軽減させることが示唆された。

本論文の要旨は第13回日本脳卒中学会総会 (昭和63年, 東 京）に扔いて発表した。

\section{文献}

1) Masuda J, Tanaka K, Omae T, et al: Cerebrovascular diseases and their underlying vascular lesions in Hisayama, Japan-A pathological study of autopsy cases. Stroke $14: 934-940$, 1983

2) Dyerberg J, Bang HO, Stoffersen E, et al: Eicosapentaenoic acid and prevention of thrombosis and atherosclerosis? Lancet II : 117-119, 1978

3) Yamori $Y$, Horie $R$, Handa $H$, et al: Pathogenetic similarity of strokes in stroke-prone spontaneously hypertensive rats and humans. Stroke 7: 46-53, 1976

4) Katayama $Y$, Sugimoto $S$, Inamura $K$, et al : Susceptibility to ischemic insult in hypertensive rats: Correlation between degree of ischemia and hypertension. Jpn Circ J $50: 258-264,1986$

5）片山泰朗, 杉本 繁, 鈴木 悟ら : 高血圧自然ラッ 卜（SHR）を使用した実験的脳虚血急性期に打け る降圧治療の影響。脳卒中 9:291-297, 1987

6) Terano $T$, Hirai A, Hamazaki $T$, et al: Effect of oral administration of highly purified eicosapentaenoic acid on platelet function, blood viscosity and red cell deformability in healthy human subjects. Atherosclerosis $46: 321$ $-331,1983$

7) Vane GCM, Luten JB, Brongeest SHO, et al: Effect on serum lipid levels of $\omega-3$ fatty acids of ingesting fish oil concentrate. Lancet II : 1249 $-1250,1979$

8) Siess W, Roth P, Scherer B, et al: Plateletmembrane fatty acid, platelet aggregation and thromboxane formation during a mackerel diet. Lancet I : 441-444, 1980 
9) Kobayashi S, Hamazaki T, Hirai A, et al: Epidemiological and clinical studies of the effect of eicosapentaenoic acid (EPA, C20:5 $\omega$-3) on blood viscosity. Clin Hemorrheology 5 : 493 $-505,1985$

10) Fischer S, Weber PC: Prostaglandin $I_{3}$ is formed in vivo in man after dietary eicosapntaenoic acid. Nature 307 : 165-168, 1984

11) Dyerverg J : Dietary manipulation of prostaglandins synthesis: Beneficial or detrimental? Cardiovascular Pharmacology of the Prostaglandins. ed by Herman AG, Vanhoutte PM, Denolin H, et al, pp223-244, Ravan Press, New York, 1982

12) Needleman P, Raz A, Minkes MS, et al: Triene prostaglandins : Prostacyclin and thromboxane biosynthesis and unique biological properties. Proc Natl Acad Sci USA 76: 944-948, 1979

13) Lorenz R, Spengler U, Fischer S, et al : Platelet function, thromboxane formation and blood pressure control during supplementation of the western diet with cod liver oil. Circulation 67 : 504-511, 1984

14) Singer $P$, Jaeger W, Wirth $M$, et al : Lipid and blood pressure lowering effect of mackerel diet in man. Atherosclerosis 49:99-108, 1983

15）家森幸男, 奈良安雄, 木原正博ら：脳卒中易発症 ラットの脳卒中発症におけるプロスタグランディ ンの役割。血液と脈管 $12: 260-262,1981$

16）田村 泰, 平井愛山, 吉田 尚：エイコサペンタエ ン酸代謝と血栓症. 内科 $54: 433-437,1984$

17) Lossonczy TO, Ruiter A, Bronsgeest SHC, et al: The effect of a fish diet on serum lipids in healthy human subjects. Am J Clin Nutr 31 : $1340-1346,1978$

18) Karatake $Y$, Hirahara F, Innami $S$, et al : Dietary effect of $\omega-3$ polyunsaturated fatty acid on serum and liver lipid levels in rats. J Nutr Sci Vitaminol 29:11-21, 1983

19) Morita I, Takahashi R, Saito $Y$, et al : Effects of eicosapentaenoic acid on arachidonic acid metabolism in cultured vascular cells and platelets: Species difference. Throm Res 31: 211-217, 1983

20) Morita I, Saito Y, Chang WC, et al : Effects of purified eicosapentaenoic acid on arachidonic acid metabolism in cultured murine aortic smooth muscle cells, vessel walls and platelets. Lipid 18: 42-44, 1983

21) Morita I, Komeshima N, Takahashi R, et al : A proposed method for exploring antiaggregatory effects of eicosapentaenoic acid in the rat. Prostaglandins Leukotrienes Med 14 : 123-129, 1984

22) Dietrich WD, Busto R, Ginsberg MD: Cerebral endothelial microvilli formation following global forebrain ischemia. J Neuropath Exp Neurosurg 43:72-83, 1984

23) Hazama F, Ozaki T, Amano S: Scanning electron microscopic study of endothelial cells of cerebral arteries from spontaneously hypertensive rats. Stroke 10:245-252, 1979

24) Black KL, Hoff JT, Radin NS, et al : Eicosapentaenoic acid : Effect on brain prostaglandins, cerebral blood flow and edema in ischemic gerbils. Stroke 15 : 65-69, 1984

25）於保倫之助, 添田敏幸, 飯田 恵ら：SHRSP の加 齢と局所脳血流 ; オートラジオグラフィー法によ る検討. 第 24 回 SHR 学会抄録集, 24, 1987

26) Ochi K, Yoshimoto $T$, Yamamoto $S$, et al: Arachidonate 5-lipoxygenase of guinea pig peritoneal polymorphonuclear leukocytes. J Biol Chem 258 : 5754-5758, 1983

27) Minamisawa $H$, Terashi A, Katayama $Y$, et al : Brain eicosanoid levels in spontaneously hypertensive rats after ischemia with reperfusion: Leukotriene $\mathrm{C}_{4}$ as a possible cause of cerebral edema. Stroke $19: 372-377,1988$

28) Terano T, Salmon JA, Moncada S: Effect of orally administered eicosapentaenoic acid (EPA) on the formation of leukotriene $\mathrm{B}_{4}$ and leukotriene $B_{5}$ by rat leukocytes. Biochem Pharmacol 33 : 3071-3076, 1984

29) Goldman DW, Pickett WC, Goetzl EJ : Human neutrophil chemotactic and degranulating activities of luekotriene $\mathrm{B}_{5}\left(\mathrm{LTB}_{5}\right)$ derived from eicosapentaenoic acid. Biochem Biophys Res Commun 117 : 282-288, 1983

30) Nathaniel DJ, Evans JF, Leblanc Y, et al : Leukotriene $A_{5}$ is a substrate and an inhibitor of rat and human and human neutrophil $\mathrm{LTA}_{4}$, hydrolase. Biochem Biophys Res Commun 131 : $827-835,1985$ 


\title{
Abstract \\ Effect of long term administration of eicosapentaenoic acid (EPA) on survival, lipid metabolism, endothelium of middle cerebral artery (MCA) and experimental cerebral ischemia in stroke-prone spontaneously hypertensive rat (SHRSP)
}

\author{
Fumihiko Kashiwagi, M.D., Yasuo Katayama, M.D., Hajime Memezawa, M.D. \\ and Akiro Terashi, M.D. \\ Second Department of Internal Medicine, Nippon Medical School
}

Effect of long term administration of eicosapentenoic acid (EPA) in stroke-prone spontaneously hypertensive rats (SHRSP) was studied. Survival, plasma lipid and endothelium of middle cerebral arteries (MCA) were investigated after administration of EPA for 25 weeks. Effect of EPA on acutely-induced cerebral ischemia was also studied. Eicosanoids play an important role in development of arteriosclerosis and occurrence of cerebral ischemia. EPA suppreses platelet aggregation and inhibits arachidonate conversion into thromboxane $A_{2}$ and other prostaglandins. EPA is also itself oxidized by cyclooxygenase and lipoxygenase, and $\mathrm{TXA}_{3}$ and $\mathrm{LTB}_{5}$ derived from EPA show less potent biological actions compared to $\mathrm{TXA}_{2}$ and $\mathrm{LTB}_{4}$ from arachidonate. Therefore administration of EPA might reduce development of arteriosclerosis and the brain damage from ischemic insult. The objective of this study is to investigate the effect of EPA on brain edema and metabolites in cerebral ischemia.

Eight weeks old male SHRSP were used for experiment. SHRSP were fed either a standard diet (control) or a diet supplemented with EPA (100 mg/kg/day) for 25 weeks. At 33 weeks old, plasma lipids were analyzed and luminal surfaces of MCA were investigated using scanning electron microscopy (SEM). In the same aged rats, cerebral ischemia was induced by bilateral common carotid artery occlusions (BLCO), and brain edema and metabolites (ATP, lactate, pyruvte) were determined $3 \mathrm{hr}$ after BLCO.

In total plasma fatty acid composition, eicosapentaenoate (20:5) increased in the EPA administrated group, while the level of arachidonate (20:4) were not changed. In the SEM observation of MCA, a lot of microvilli, hypertrophy of marginal folds, shrinkage of endothelium and RBC trapped by fibrin nets were observed in the control group. While these degenerative changes were slight in the treated group. In the experiment of cerebral ischemia, brain water content in the EPA group was significantly lower and pyruvate was higher than in the control gorup, while there were no differences in the levels of ATP and lactate between the both groups.

These findings indicate that administration of EPA reduces ischemic damage, especially brain edema as well as degenerative changes of endothelium in non-ischemic SHRSP through influence on arachidonate metabolism.

(Jpn. J. Stroke 12: 326-333, 1990) 